\title{
The ReSVinet Score for Bronchiolitis: A Scale for All Seasons
}

\author{
Antonio José Justicia-Grande, $\mathrm{MD}^{1,2}$ Federico Martinón-Torres, MD, $\mathrm{PhD}^{1,2}$ \\ 1 GENVIP Group (Genética, Vacunas, Infecciones y Pediatría), Instituto \\ de Investigación Sanitaria de Santiago de Compostela, Santiago de \\ Compostela, Spain \\ ${ }^{2}$ Translational Paediatrics and Infectious Diseases Unit, Department \\ of Paediatrics. Hospital Clínico Universitario de Santiago de \\ Compostela, A Coruña, Spain \\ Address for correspondence Federico Martinón-Torres, MD, PhD, \\ Translational Paediatrics and Infectious Diseases Unit, Department of \\ Paediatrics, Planta -1, Hospital Clínico Universitario de Santiago de \\ Compostela, Travesía da Choupana, s/n, Santiago de Compostela \\ 15706, Spain (e-mail: Federico.Martinón-Torres@sergas.es).
}

Am J Perinatol 2019;36(suppl S2):S48-S53.

\author{
Abstract \\ Keywords \\ - clinical scale \\ - respiratory difficulty \\ - validation \\ - wheezing \\ - asthma \\ - bronchiolitis \\ - mHealth intervention
}

The ReSVinet Scale is a clinical score for the assessment of respiratory difficulty in infancy. Our aim was to provide an update on the characteristics that make this tool different to any other. We descriptively compared the characteristics of the ReSVinet Scale with other options that can be found in the current literature or mobile apps stores. The ReSVinet Scale has been devised for its use regardless of the age of the child, entity causing respiratory symptoms, and setting. To this date, it is the only pediatric respiratory scale for acute respiratory distress that provides a parental version, and it is also the first one to have undergone validation in primary care. The tool can be found either in paper format or can be downloaded via App stores for devices running on Android or iOS systems. It has also been adopted recently as the assessment instrument for several clinical trials and for an IMI2 initiative (RESCEU project). All the aforementioned characteristics of the ReSVinet Scale should help toward its dissemination, as currently no other clinical tool for the assessment of respiratory difficulty can offer those advantages.
Assessment of respiratory difficulty is critical in pediatric daily practice. Asthma is the most prevalent condition in infancy in the developed world, whereas deaths caused by respiratory infections weigh heavily on underdeveloped countries. ${ }^{1}$ Pulmonary function tests are usually not suitable for infants, and a noninvasive and simple clinical scoring system that can discriminate correctly the severity of the disease would be highly appreciated. Currently, healthcare providers must make a choice among a swarming number of pediatric respiratory scales. This stresses not only the importance of these tools but also the lack of a gold standard, as results obtained through any particular scale reflect a subjective evaluation. Difficulties for interpreting those results rise when scales employed by investigators are not the same, because different tools are usually devised for different illnesses, thought for its use in different age groups, and require different exclusion and inclusion criteria, thus making comparisons unfeasible. ${ }^{2}$ It is here when validation steps in. Validation is a consensual process that was developed to ascertain if the results provided by a scale are repeatable, reliable, and hassle-free. Validation also allows professionals to compare two tools using different components. But recent reviews of published pediatric scores have detected several deficiencies: there is currently no perfectly validated clinical score. ${ }^{3}$ Scales are being developed to be used only by healthcare providers, evaluating either children presenting in emergency departments (EDs) or those who have been admitted to a hospital. That means that, in infants, no one of these scales has been validated for its use in primary care. ${ }^{2}$

Bearing the previous assumptions in mind, we aimed to develop a clinical tool for assessing acute respiratory difficulty in children, suitable for all ages, and that could be used regardless of the etiology of the distress or lack of clinical expertise. We devised transversal validation processes, aiming to test the characteristics of the scale both in hospitalary and primary care settings.
Copyright (c) 2019 by Thieme Medical Publishers, Inc., 333 Seventh Avenue, New York, NY 10001, USA. Tel: +1(212) 584-4662. ISSN 0735-1631. 


\section{The ReSVinet Scale}

The ReSVinet Scale is composed of seven items-feeding intolerance, medical intervention, respiratory difficulty, respiratory frequency, apnea, general condition, and fever. Each item is scored from 0 to 3 (more severe), except apnea (can only take a 0 or 3 value) and fever $(0,1$, or 2$)$. Total value of the score after summing up all components ranges between 0 and 20. It is available in two versions: one designed for parental assessment (-Fig. 1) and other one for professional use (-Fig. 2). In 2016, we published the results of the validation of both versions of the ReSVinet Scale in a homogeneous sample of 170 children $<2$ years who have been admitted to hospital wards due to an acute respiratory infection. ${ }^{4}$ Internal consistency was found to be good (Cronbach's $\alpha>0.70$ ). In our study, in-situ evaluations of the legal guardians were comparable to those extracted by clinicians from clinical records (interobserver reliability $k=$ 0.73). Although parental opinion on the overall severity of respiratory symptoms has been reported previously by some authors, they used no composite scale. Thus, the ReSVinet Scale was the first clinical tool that provided a parental version of any scoring system for acute respiratory distress. ${ }^{2}$

\section{A Scale for All Seasons}

We next tackled an important gap we had identified in the literature. Our scoring system underwent validation in primary care. It is in this context where a fast, noninvasive tool that can reliably categorize patients could be more helpful. Using the ReSVinet Scale, 11 pediatricians independently assessed 241 infants presenting in their primary care practices with any cause of respiratory difficulty. Inter-rater reliability between parents and physicians was acceptable $(k=0.71)$. Internal consistency using Cronbach's $\alpha$ was 0.62 for physicians and 0.67 for pediatricians, and it reached values $>0.70$ when analyzing subgroups with the same diagnosis (information presented at the Meeting of the European Society for Pediatric Infectious Diseases, available at: https://espid2017. kenes.com/Documents/ESPID17\%20abstracts.pdf). The ReSVinet Scale has been more extensively validated than any other similar score, although data from the reliability domain has still to be obtained and apprehended. Combining data from both validation studies, cut-points for our scale were defined as following: $0-6$ for mild affection, $7-13$ for moderate distress, and 14-20 for severe respiratory affection.

\section{Mobile Health Intervention}

In consonance with our interconnected world, scales can be delivered directly to wireless devices. The World Health Organization has announced that mobile Health (mHealth) has a global potential to change the way health services are delivered. ${ }^{5}$ What is more, mobile apps may offer new opportunities for reducing the barrier in accessing and using health information and health services, and among low-income populations mobile apps seem to be more acceptable than web-based interventions. ${ }^{6}$ Despite these claims, we should realize that there is still a paucity of information about the characteristics of apps for acute respiratory scores. Most of the literature that reviews mHealth interventions has detected the use of control scores (asthma control test [ACT], asthma control questionnaire [ACQ], control of allergic rhinitis and asthma test [CARAT]) or Quality of Life Questionnaires. $^{7,8}$ Control scores, like ACT and ACQ do not provide a valid measure of severity of asthma exacerbation, less for laryngitis, bronchiolitis, or other short-term entities.

We have conducted our own survey of literature repositories, paired with a systematic search in app stores of Android, iOS, and Windows Phones (unpublished report), and we have found that apps that offer the possibility of introducing data to assess the severity of acute-onset respiratory distress using a respiratory score normally contain Wood-Downes and Tal scores for bronchiolitis, Westley and Taussig scales for laryngitis, and pediatric respiratory assessment measure (PRAM) and pulmonary scores for asthma exacerbation. mHealth apps containing control tools are marketed normally for patients and/or their parents, but resources aiming at evaluating the difficulty of acute-onset respiratory distress are almost universally designed for clinicians. Although we have found one mHealth intervention, providing the Pediatric Observation Priority Score, ${ }^{9}$ that allows users to identify themselves as "other," it should be noted that this scale has been validated only for ED clinical teams, as it aims to support clinical decisions of staff who are not familiar with children. ${ }^{10}$ Other apps, like HandiPediatric, ${ }^{11}$ are indeed devised for parental use, but they do not actually use a composite score and adopt a tiered approach instead, sorting symptoms using a color code, where red requires immediate assessment by a physician.

Given the wide array of scores available for assessing acute respiratory distress, downloading all the available apps can be a cumbersome experience for any clinician; and once stored in the hard disk of the device, the user must struggle to remember the specific subpopulation for which an specific score has been designed-for example, use of P.R.A.M score is intended only for decision making in EDs.

Some developers have tried to tackle this issue offering several scores in a unique mHealth solution, thus "compiling" a list of scores devised for distinct diseases (respiratory, neurological, trauma...). When available, respiratory scales for acute distress are usually marketed under the "pediatric" heading of "score compilation" apps, thus meaning that apps envisioned for internists or for specialist other than pediatricians often lack those scales. Even in the case of downloading a score-compiler app with the "Pediatrician" heading, there is a high chance that the scores contained are limited to the Silverman Score or Apgar Score, which can only be applied to newborns. And if the program selected does happen to provide another scale for acute respiratory difficulty, reasons that led to the selection of that particular tool over the other possibilities are never explained. Also, meanwhile apps for control scores offer the option to save the data for future consultation and even can depict the evolution of symptoms in a graphic, ${ }^{7,8}$ mHealth solutions for acute respiratory difficulty lack this feature. 
S50 The ReSVinet Score for Bronchiolitis Justicia-Grande et al.

Guidelines:

- For each item, please select the option best describing the clinical status of the child.

- Each item should be given a value between 0 and 3 . Please, note that Item "Apnea" can only be either 0 or 3 , and that Item "Fever" values range from 0 to 2.

- The final Total Score ranges from 0 to 20.
Subject ID:

Date:

\section{The ReSVinet Scale (Parental Version)}

\begin{tabular}{|c|c|c|c|c|c|c|}
\hline \multicolumn{2}{|r|}{ ITEM } & 0 points & 1 point & 2 points & 3 points & POINTS \\
\hline 1 & $\begin{array}{l}\text { Feeding } \\
\text { Intolerance }\end{array}$ & No & $\begin{array}{l}\text { Mild } \\
\text { Decreased appetite (the } \\
\text { child did not eat the } \\
\text { same as usually) and/or } \\
\text { presented isolated } \\
\text { vomits (with or without } \\
\text { cough). }\end{array}$ & $\begin{array}{l}\text { Partial } \\
\text { Frequent vomits with } \\
\text { cough, but the child does } \\
\text { not vomit with every } \\
\text { intake. Feeding exhausts } \\
\text { the child. }\end{array}$ & $\begin{array}{l}\text { Total } \\
\text { Child is unable to feed } \\
\text { him/herself. The use of a } \\
\text { nasogastric tube or } \\
\text { parenteral nutrition was } \\
\text { required. }\end{array}$ & \\
\hline 2 & $\begin{array}{l}\text { Medical } \\
\text { Intervention }\end{array}$ & No & $\begin{array}{l}\text { Basic } \\
\text { The child's respiratory } \\
\text { secretions required } \\
\text { removal, he or she was } \\
\text { explored by a physician } \\
\text { or received sporadically } \\
\text { nebulized medication. } \\
\text { Antipyretics were } \\
\text { administered. }\end{array}$ & $\begin{array}{l}\text { Intermediate } \\
\text { The child required } \\
\text { oxygen therapy, } \\
\text { underwent a chest X-ray } \\
\text { exploration, or a blood } \\
\text { sample was extracted. } \\
\text { Treatment with } \\
\text { nebulized drugs was } \\
\text { regularly given. }\end{array}$ & $\begin{array}{l}\text { High } \\
\text { The child required } \\
\text { respiratory support with a } \\
\text { machine. Respiratory } \\
\text { support was given through } \\
\text { a special mask applied on } \\
\text { the nose or mouth or } \\
\text { resting on the child's face, } \\
\text { or through an } \\
\text { endotracheal tube. }\end{array}$ & \\
\hline 3 & $\begin{array}{l}\text { Respiratory } \\
\text { Difficulty }\end{array}$ & No & $\begin{array}{l}\text { Mild } \\
\text { The child was not } \\
\text { breathing normally, but } \\
\text { he/she does not seem to } \\
\text { have any difficulty when } \\
\text { drawing air. }\end{array}$ & $\begin{array}{l}\text { Moderate } \\
\text { The child made an effort } \\
\text { for breathing. Respiratory } \\
\text { noises can be heard } \\
\text { without the need of a } \\
\text { stethoscope (just } \\
\text { approaching the ear to his } \\
\text { or her chest). }\end{array}$ & $\begin{array}{l}\text { Severe } \\
\text { Respiratory effort was } \\
\text { obvious. The child made } \\
\text { important movements with } \\
\text { his/her chest, the chest } \\
\text { even collapses with every } \\
\text { movement, and muscles of } \\
\text { neck and belly were used. } \\
\text { A lot of respiratory noise } \\
\text { could be heard without } \\
\text { approaching the ear to the } \\
\text { child's chest. }\end{array}$ & \\
\hline 4 & $\begin{array}{l}\text { Respiratory } \\
\text { Frequency }\end{array}$ & Normal & $\begin{array}{l}\text { Mild or occasional } \\
\text { tachypnea The child } \\
\text { breathed more rapidly, } \\
\text { but the situation was well } \\
\text { tolerated, or the } \\
\text { respiratory frequency was } \\
\text { normalized after } \\
\text { removing secretions from } \\
\text { respiratory airways or } \\
\text { after administering } \\
\text { nebulized medication. }\end{array}$ & $\begin{array}{l}\text { Prolonged or recurrent } \\
\text { tachypnea } \\
\text { The child breathed more } \\
\text { rapidly in a more } \\
\text { persistent manner, even } \\
\text { after receiving nebulized } \\
\text { medication or removing } \\
\text { secretions from } \\
\text { respiratory tract. }\end{array}$ & $\begin{array}{l}\text { Severe alteration } \\
\text { The child breathed quickly } \\
\text { and superficially, or really } \\
\text { deeply. The child was } \\
\text { agitated or drowsy. }\end{array}$ & \\
\hline 5 & Apnea & No & & & $\begin{array}{l}\text { Yes } \\
\text { The child stopped breathing. } \\
\text { It may have been necessary } \\
\text { to stimulate him/her in } \\
\text { order to regain a normal } \\
\text { breathing rate. }\end{array}$ & \\
\hline 6 & $\begin{array}{l}\text { General } \\
\text { Condition }\end{array}$ & Normal & $\begin{array}{l}\text { Mild } \\
\text { Child did not seem to be } \\
\text { the same as always, } \\
\text { maybe he/she was feeling } \\
\text { a little uncomfortable, but } \\
\text { there did not seem to be } \\
\text { anything to worry about. }\end{array}$ & $\begin{array}{l}\text { Moderate } \\
\text { Child looked ill, and } \\
\text { medical examination was } \\
\text { required, but it just did } \\
\text { not feel like a life- } \\
\text { threatening situation. }\end{array}$ & $\begin{array}{l}\text { Severe } \\
\text { Child was agitated, } \\
\text { apathetic,and/or lethargic. } \\
\text { He/she required urgent } \\
\text { medical attention. There } \\
\text { was no need to be a doctor } \\
\text { to realize that the clinical } \\
\text { situation of the child was } \\
\text { worrisome. }\end{array}$ & \\
\hline 7 & Fever & No & $\begin{array}{l}\text { Yes, mild } \\
\text {-Rectal or tympanic } \\
\text { temperature } \geq 38^{\circ} \mathrm{C} \text { and }< \\
38.5^{\circ} \mathrm{C} \text {, or } \\
\text {-Axillar temperature } \\
237.5^{\circ} \mathrm{C} \text { and }<38^{\circ} \mathrm{C}\end{array}$ & $\begin{array}{l}\text { Yes, moderate } \\
\text {-Rectal or tympanic } \\
\text { temperature } \geq 38.5^{\circ} \mathrm{C} \text {, or } \\
\frac{- \text { Axillar temperature } \geq}{38^{\circ} \mathrm{C}}\end{array}$ & & \\
\hline & & & & & TOTAL SCORE & \\
\hline
\end{tabular}

Fig. 1 The parental version of the ReSVinet Scale. 
The ReSVinet Score for Bronchiolitis Justicia-Grande et al. S51

Guidelines:

- For each item, please select the option best describing the clinical status of the patient.

- Each item should be given a value between 0 and 3 . Please, note that Item "Apnea" can only be either 0 or 3 , and that Item "Fever" values range from 0 to 2. - The final Total Score ranges from 0 to 20
Subject ID:

Date:

\section{The ReSVinet Scale (Professional)}

\begin{tabular}{|c|c|c|c|c|c|c|}
\hline \multicolumn{2}{|r|}{ ITEM } & 0 points & 1 point & 2 points & 3 points & \multirow[t]{2}{*}{ POINTS } \\
\hline 1 & $\begin{array}{l}\text { Feeding } \\
\text { Intolerance }\end{array}$ & No & $\begin{array}{l}\text { Mild } \\
\text { Decreased appetite and/or } \\
\text { isolated vomits with cough. }\end{array}$ & $\begin{array}{l}\text { Partial } \\
\text { Frequent vomits with } \\
\text { cough, rejected feed but } \\
\text { able to tolerate fluids } \\
\text { sufficiently to ensure } \\
\text { hydration. }\end{array}$ & $\begin{array}{l}\text { Total } \\
\text { Oral intolerance or absolute } \\
\text { rejection of oral feed, not } \\
\text { able to guarantee adequate } \\
\text { hydration orally. Required } \\
\text { nasogastric and/or } \\
\text { intravenous fluids }\end{array}$ & \\
\hline 2 & $\begin{array}{l}\text { Medical } \\
\text { Intervention }\end{array}$ & No & $\begin{array}{l}\text { Basic } \\
\text { Nasal secretions aspiration, } \\
\text { physical examination, trial } \\
\text { of nebulized } \\
\text { bronchodilators, } \\
\text { antipyretics. }\end{array}$ & $\begin{array}{l}\text { Intermediate } \\
\text { Oxygen therapy required. } \\
\text { Complementary exams } \\
\text { were needed (chest X-rays, } \\
\text { blood gases, } \\
\text { hematimetry...). Maintained } \\
\text { nebulized therapy with } \\
\text { bronchodilators. }\end{array}$ & $\begin{array}{l}\text { High } \\
\text { Required respiratory } \\
\text { support with positive } \\
\text { pressure (either non- } \\
\text { invasive in CPAP, BiPAP or } \\
\text { high-flow O2; or invasive } \\
\text { through endotracheal tube). }\end{array}$ & \\
\hline 3 & $\begin{array}{l}\text { Respiratory } \\
\text { Difficulty }\end{array}$ & No & $\begin{array}{l}\text { Mild } \\
\text { Not in basal situation but } \\
\text { does not appear severe. } \\
\text { Wheezing only audible with } \\
\text { stethoscope, good air } \\
\text { entrance. If modified Wood } \\
\text { Downes, Wang score or any } \\
\text { other respiratory distress } \\
\text { score is applied, it indicates } \\
\text { mild severity. }\end{array}$ & 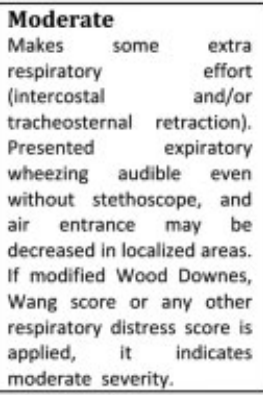 & $\begin{array}{l}\text { Severe } \\
\text { Respiratory effort is } \\
\text { obvious. Inspiratory and } \\
\text { expiratory wheezing and/or } \\
\text { clearly decreased air entry. } \\
\text { If modified Wood Downes, } \\
\text { Wang score or any other } \\
\text { respiratory distress score is } \\
\text { applied, it indicates high } \\
\text { severity. }\end{array}$ & \\
\hline 4 & $\begin{array}{l}\text { Respiratory } \\
\text { Frequency }\end{array}$ & $\begin{array}{l}\text { Normal } \\
<2 \mathrm{~m}: 40-50 \mathrm{bpm} \\
2-6 \mathrm{~m}: 35-45 \mathrm{bpm} \\
6-12 \mathrm{~m}: 30-40 \mathrm{bpm} \\
12-24 \mathrm{~m}: 25-35 \mathrm{bpm} \\
24-36 \mathrm{~m}: 20-30 \mathrm{bpm}\end{array}$ & $\begin{array}{l}\text { Mild or occasional } \\
\text { tachypnea Presented } \\
\text { episodes of tachypnea, well } \\
\text { tolerated, limited in time by } \\
\text { self-resolution or response } \\
\text { to secretion aspiration or } \\
\text { nebulization. }\end{array}$ & $\begin{array}{l}\text { Prolonged or recurrent } \\
\text { tachypnea } \\
\text { Tachypnea persisted or } \\
\text { recurred despite secretion } \\
\text { aspiration and/or } \\
\text { nebulization with } \\
\text { bronchodilators. }\end{array}$ & $\begin{array}{l}\text { Severe alteration } \\
\text { Severe and sustained } \\
\text { tachypnea. Very superficial } \\
\text { and quick breath rate. } \\
\text { Normal/low breath rate } \\
\text { with obvious increased } \\
\text { respiratory effort and/or } \\
\text { mental status affected. } \\
\text { Orientative rates of severe } \\
\text { tachypnea: } \\
<2 \mathrm{~m}:>70 \mathrm{bpm} \\
2-6 \mathrm{~m}:>60 \mathrm{bpm} \\
6-12 \mathrm{~m}:>55 \mathrm{bpm} \\
12-24 \mathrm{~m}:>50 \mathrm{bpm} \\
24-36 \mathrm{~m}:>40 \mathrm{bpm}\end{array}$ & \\
\hline 5 & Apnea & No & & & $\begin{array}{l}\text { Yes } \\
\text { At least one episode of } \\
\text { respiratory pause medically } \\
\text { documented or strongly } \\
\text { suggested } \\
\text { anamnesis. }\end{array}$ & \\
\hline 6 & $\begin{array}{l}\text { General } \\
\text { Condition }\end{array}$ & Normal & $\begin{array}{l}\text { Mild } \\
\text { Not in basal situation, child } \\
\text { was mildly uncomfortable } \\
\text { but does not appear to be in } \\
\text { a severe condition not } \\
\text { impress of severity. Parents } \\
\text { are not alarmed. Could wait } \\
\text { in the waiting room or even } \\
\text { stay at home. }\end{array}$ & $\begin{array}{l}\text { Moderate } \\
\text { Patient looks ill, and will } \\
\text { need medical exam and } \\
\text { eventually further } \\
\text { complementary exams } \\
\text { and/or therapy. Parents are } \\
\text { concerned. Cannot wait in } \\
\text { the waiting room. }\end{array}$ & $\begin{array}{l}\text { Severe } \\
\text { Agitated, apathetic, } \\
\text { lethargic. No need of } \\
\text { medical training to realise } \\
\text { severity. Parents are very } \\
\text { concerned. Immediate } \\
\text { medical evaluation and/or } \\
\text { intervention was required. }\end{array}$ & \\
\hline 7 & Fever & No & $\begin{array}{l}\text { Yes, mild } \\
- \text { Central } T \geq 38^{\circ} \mathrm{C} \text { and }< \\
38.5^{\circ} \mathrm{C}\end{array}$ & $\begin{array}{l}\text { Yes, moderate } \\
\text { Central } \mathrm{T} \geq 38.5^{\circ} \mathrm{C} \text { or }<35^{\circ} \mathrm{C}\end{array}$ & & \\
\hline & & & & & TOTAL SCORE & \\
\hline
\end{tabular}

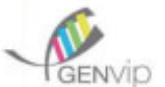

Fig. 2 The ReSVinet Scale for healthcare professionals. 
This is why we decided to build an app containing both versions of our score: the ReSVinet Scale App. The ReSVinet Scale App simplifies the process of choosing a clinical scale appropriate for each cause of respiratory distress, or that is suited to the age of each patient. For each version of the ReSVinet Scale, this mHealth solution offers users two possibilities: a fast option for those who already known the ReSVinet Scale, and a step-by-step choice that guides newcomers through infant assessment using oriented, itemrelated questions. It is possible to save the requested data for each episode, as well as associated information, to retrieve it later. The mobile solution hit the Market in October 2017. The ReSVinet Scale App is therefore available for both clinicians and legal guardians in Google Play (https:// play.google.com/store/apps/details?id=org.ejkc.resvinet\&hl=en_US) and AppStore (https://itunes.apple.com/us/ app/resvinet-score/id1284710379? $\mathrm{mt}=8) .{ }^{12}$

The ReSVinet Scale App is currently undergoing iterative testing and being translated to several languages to provide both clinicians and parents who are not fluent with English an adapted tool.

\section{Current and Future Lines of Work}

Respiratory sores are normally tailored to be tested in very specific populations, usually on patients suffering from one specific disease and falling within a restricted age range. This homogeneity bolsters results of statistical tests, but it is rarely the scenario found on EDs or doctors' practices. Children usually present with overlapping symptoms that can be attributed to more than one entity, like bronchiolitis and pneumonia, the latter being easily an exclusion criterion in many validation studies for bronchiolitis-designed scores. ${ }^{2}$ In the end, these restrictions pave the way for scale misusage, bending the limits of age imposed by the scale or employing it outside the setting for which it was validated. ${ }^{2}$ Those problems are avoided when using a more practical scale like the ReSVinet Scale.

Despite all the milestones we have achieved, there is still a lot of room for improvement. Although the ReSVinet Scale has yielded better results than any other respiratory score when testing their validation characteristics, ${ }^{2}$ information on responsiveness and measurement error needs still to be provided. Future lines of work include testing the reliability component of validation, gather parental feedback from app usage, and ascertain whether there are any differences between paper and mHealth assessment. Evidence on the effect of mHealth interventions has only been obtained for SMS use, and the equivalence of apps to other validated interventions remains to be seen. ${ }^{13}$

Our score has been selected for several clinical trials. ${ }^{14-16}$ It has been included in an IMI2 funded project (RESCEU) (http://resc-eu.org), aiming at recruiting over 10.000 children across all Europe. This will add more data to new validation processes, help understand cultural perceptions in respiratory difficulty, and provide further field for app testing. Continuous use and feedback on mHealth interventions are critical, as marketed apps present a rapid turnover, with $28 \%$ of asthma-designed apps disappearing in a lapse of 2 years. ${ }^{8}$ Meanwhile, the availability of a scale for professionals and parents that has been validated across hospital and primary care could improve communication between healthcare providers and main caregivers when monitoring children with respiratory difficulty, and in greater parental involvement in patient management.

\section{Conclusion}

- The ReSVinet Scale is the only existing tool allowing legal guardians to assess the respiratory difficulty of their children in a way that can be compared with that of a physician.

- The ReSVinet Scale is the only clinical respiratory scale for acute respiratory difficulty in children that has been validated in a primary care setting.

- The ReSVinet Scale, in contrast with other scales tested in restrictive conditions and aimed at assessing one agespecific disease, has been developed to tackle any cause of respiratory difficulty in all the pediatric population.

- The ReSVinet Scale App delivers some features that other similar mHealth solutions lack, like the option of saving the assessments for future reference, the possibility of including additional information to each evaluation, and the provision of a parental version of a clinical scale. Those characteristics can be found in programs for control scores, but not in apps containing "acute" scores."

- There are still areas of validation of the ReSVinet Scale that are currently being tested, like the reliability domain. Those tests will be bolstered by the evaluations made using the ReSVinet Scales in several ongoing clinical trials and observational studies.

\section{Ethical Approval}

Investigations concerning the development and testing of the ReSVinet Scale were granted approval by the regional Ethics Committee in Galicia (registration number 2010/ 015). Written informed consent was gathered from all legal guardians prior to subject inclusion.

\section{Funding}

FMT research activities are supported by Instituto de Salud Carlos III (Proyecto de Investigación en Salud, Acción Estratégica en Salud) project ReSVinext ISCIII/ PI16/01569/Cofinanciado FEDER.

Conflict of Interest

None declared.

\section{References}

1 Al-Durra M, Torio MB, Cafazzo JA. The use of behavior change theory in Internet-based asthma self-management interventions: a systematic review. J Med Internet Res 2015;17(04):e89

2 Justicia-Grande AJ, Pardo Seco J, Rivero Calle I, Martinón-Torres F. Clinical respiratory scales: which one should we use? Expert Rev Respir Med 2017;11(12):925-943 
3 Bekhof J, Reimink R, Brand PL. Systematic review: insufficient validation of clinical scores for the assessment of acute dyspnoea in wheezing children. Paediatr Respir Rev 2014;15(01): 98-112

4 Justicia-Grande AJ, Pardo-Seco J, Cebey-López M, et al; Respiratory Syncytial Virus network (ReSVinet). Development and validation of a new clinical scale for infants with acute respiratory infection: the ReSVinet scale. PLoS One 2016;11(06): e0157665

5 eHealth. WHOGOF. New Horizons for Health through Mobile Technologies. Geneva: World Health Organization; 2011

6 Turner-McGrievy GM, Hales SB, Schoffman DE, et al. Choosing between responsive-design websites versus mobile apps for your mobile behavioral intervention: presenting four case studies. Transl Behav Med 2017;7(02):224-232

7 Bierbrier R, Lo V, Wu RC. Evaluation of the accuracy of smartphone medical calculation apps. J Med Internet Res 2014;16(02):e32

8 Huckvale K, Morrison C, Ouyang J, Ghaghda A, Car J. The evolution of mobile apps for asthma: an updated systematic assessment of content and tools. BMC Med 2015;13:58. Doi: 10.1186/s12916015-0303-x

9 Musgrove Park Hospital. P.O.P.S. 2016. Available at Google Play https://play.google.com/store/apps/details?id=uk.nhs.musgroveparkhospital.pops and App Store - https://itunes.apple.com/ hn/app/p-o-p-s/id1181419115? $\mathrm{mt}=8$

10 Roland D, Arshad F, Coats T, Davies F. Baseline characteristics of the paediatric observation priority score in emergency departments outside its centre of derivation. BioMed Res Int 2017; 2017:9060852
11 Musgrove Park Hospital. Handi Pediatric. 2018-Available at Google Play (v 2.8.2) - https://play.google.com/store/apps/details? id=com.myoxygen.handi.taunton And AppStore - https://itunes. apple.com/gb/app/handi-paediatric/id969445171?mt=8

12 Gradiant. The ReSVinet Scale App. 2019. Available at Google Play (v 1.3.8). Available at: (https://play.google.com/store/apps/ details?id=org.ejkc.resvinet\&hl=en_US) and AppStore (https:// itunes.apple.com/us/app/resvinet-score/id1284710379?mt=8

13 Marcano Belisario JS, Jamsek J, Huckvale K, O’Donoghue J, Morrison $\mathrm{CP}$, Car J. Comparison of self-administered survey questionnaire responses collected using mobile apps versus other methods. Cochrane Database Syst Rev. 2015MR000042

14 A Study to determine the epidemiology and evaluate the burden of disease in respiratory syncytial virus/human metapneumovirus and influenza A infected hospitalized participants (Adults and Children). Available at: https://clinicaltrials.gov/ct2/show/ NCT03574532

15 Understanding RSV: Severe Disease and the Long Term Consequences. Available at: https://clinicaltrials.gov/ct2/show/ NCT03756766? term=ReSVinet\&rank=2. Accessed May 30, 2019

16 Ablynx initiates the phase IIb "respire" study of its wholly-owned, first-in-class, inhaled anti-RSV nanobody, ALX-0171, for the treatment of RSV infections in hospitalised infants. Available at: https://www.globenewswire.com/news-release/2017/01/11/ 905176/0/en/ABLYNX-INITIATES-THE-PHASE-IIb-RESPIRESTUDY-OF-ITS-WHOLLY-OWNED-FIRST-IN-CLASS-INHALEDANTI-RSV-NANOBODY-ALX-0171-FOR-THE-TREATMENT-OFRSV-INFECTIONS-IN-HOSPITALISED-INFANTS.html. Accessed June 7, 2019 